\title{
CONSTRUCTION ON AGRICULTURAL LAND WITHOUT CHANGING THE PURPOSE AND LEGAL REGULATIONS
}

\section{G. Velkovska*}

\author{
Faculty of Economics, Trakia University, Stara Zagora, Bulgaria
}

\begin{abstract}
The conditions for construction on agricultural land without a change of use are regulated in a specific order. This Ordinance 19 of October 25, 2012.

The report is to analyze some basic legal regulations of the decree and on this basis to justify conclusions and make suggestions for correction of texts in regulation.

Moreover, the report makes a comparative analysis between the regulations for construction on agricultural land without changing the purpose and construction with change of use.

Made also make analogies with other legal norms of a fundamental nature. These are: Planning Act's territory, Law on ownership and use of agricultural land, etc.

Definite aim of the report is to answer the question about the place and role of these legal regulations in the sustainable development of the territory and in particular of agricultural lands.
\end{abstract}

Key words: territory, territory, regulations, sustainable development, property preservation.

\section{INTRODUCTION}

Construction on agricultural land is a necessary process and element of the spatial structure. In general, this process is carried out in accordance with the legal regulations reflected in the Spatial Development Act.

As stated in the text of Article 4, Paragraph 2 of the Law on the Ownership and Use of Agricultural Land [www.ciela.net], the agricultural land is allowed to construct buildings and facilities related to their use under conditions and on Order established by the Spatial Planning Act and the Law for the Conservation of Agricultural Lands.

However, the specificity of agricultural territories requires a more precise legal approach to the structure of these territories. Agricultural land, especially as an essential part of the agricultural territories, needs and is subject to a number of legal protections.

In this sense, two regimes of construction on the agricultural land in the Republic of Bulgaria are envisaged in the Bulgarian legislation:

a/ with a change of purpose; $\mathrm{b} /$ no change of purpose

\footnotetext{
*Correspondence to: Gena Velkovska, Trakia University, Faculty of Economics - Stara Zagora city,Bulgaria,e-mail: gvelkovski@abv.bg
}

According to the text of Article 2, paragraph 4 of the Agricultural Land Conservation Act [www.ciela.net], construction in agricultural lands without change of their purpose can be done for greenhouses and for linear objects under Art. 17a, para. 2, and for objects whose functions are related to the agricultural use of the land - under conditions and by an order determined by an ordinance of the Minister of Agriculture and Food and the Minister of Regional Development and Public Works.

The conditions for construction in the agricultural lands without change of purpose are regulated in Ordinance № 19 of 25 October 2012. For construction in the agricultural lands without change of their purpose, in force from 06.11.2012, issued by the Minister of Agriculture and Food and the Minister of Regional Development and Public Works, promulgated SG No. 85 of 06.11.2012 [www.ciela. net].

The subject of the report is some basic legal regulations of the above mentioned regulation. The object of consideration is the procedure for carrying out the actual construction process on the agricultural lands, without changing the purpose.

The aim of the author is to base on legal review and analysis to outline some necessary directions in the improvement of the legal 
framework in the Republic of Bulgaria in this field.

\section{Terms for construction on agricultural land.}

According to the text of Article 4, paragraph 1 of Ordinance No 19, the construction of agricultural lands is based on: a/ design or design visa b/ a detailed development plan, which shall be consistent with the applicable master plan.

In the absence of a master plan, the detailed development plan shall be accompanied by a justification for:

- Socio-economic;

- Technological;

- And the environmental acceptability of the proposed construction.

The detailed layout is based on a design assignment. The assignment for the design shall be coordinated according to the procedure of Article 125 of the Territorial Development Act.

Regarding the detailed development plans, Ordinance №19 includes other legal regulations.

According to the text of Article 4, paragraph 2 of Ordinance No 19, the detailed development plans are prepared in accordance with the requirements of Article 108 of the Spatial Development Act and Ordinance No 8 on the volume and content of spatial planning schemes and plans, Parts relating to a building plan.

In the text of Article 4, paragraph 3 of Ordinance No 19, there is another legal regulation related to the content of the detailed development plan.

In addition to the design solution for the location of buildings, buildings and facilities, the detailed development plan should contain data on the buildings and facilities located in the nearby properties.

An integral part of the detailed development plan, according to the text of Article 4, paragraph 4 of Ordinance No 19, is the explanatory note.

The explanatory note clarifies the type of buildings and facilities in compliance with the norms and conditions of construction.

What does the definition of admissible construction according to the legal regulations of Ordinance No 19 provide?
VELKOVSKA G.

According to the text of Article 5 of Ordinance No 19, the definition of admissible construction in agricultural land without change of purpose includes the following steps:

First, establishing the part of the property in which it can be built;

Second, the determination of the permissible building characteristics: density, intensity, height, construction mode and building lines;

Third, determination of the purpose of construction works and architectural-building, sanitary, hygienic, environmental and fire protection requirements.

How to determine eligible land in agricultural land?

According to the text of Article 6 of Ordinance No 19, when determining the admissible construction, account shall be taken of:

a/ the landowner's investment initiative; $\mathrm{b} /$ location and size of the property and access to it;

c/ restrictions on the use of farmland; d/ specific climatic, soil, hydrological, sanitary, landscape and environmental conditions for the site;

e/ possibilities for power supply, communication-transport service, drinking water supply and water supply for the needs of agricultural production, drainage and purification of used waters.

\section{Characteristics of the sites that can be built in agricultural land without changing the purpose.}

A basic legal regulation related to construction on agricultural land without change of purpose is the regulation from the text of Article 2, paragraph 1 of Ordinance No 19.

According to the text of Art. 2, para 1, the construction on agricultural lands, without changing the purpose, is allowed for sites, which are closely related to the use of the agricultural land as intended.

This means that the functions of each construction site built on agricultural land without a change of purpose must perform functions that are in line with the purpose of that agricultural land.

The text of Article 2, paragraph 1 of Ordinance No 19 includes two types of objects, which can be built on agricultural land without a change of purpose.

The characteristics of these sites are placed in direct dependence on the area of the agricultural property, namely: 
a/ For properties with an area of up to 10 decares the construction of one-storey agricultural buildings for storing agricultural produce and inventory and living space is permitted;

b/ For properties with an area of more than 10 decares, the construction of agricultural buildings, buildings and facilities for the storage of plant and livestock and animal breeding, as well as of engineering networks and facilities for the development of the properties and living quarters of Landowners and their families and those who produce agricultural produce from agricultural land.

What are the norms for building on agricultural land, without changing the purpose, should construction be carried out?

According to the regulation of the text of Article 7, paragraph 1 of Ordinance No 19, the building area can reach up to $10 \%$ of the total area of the property.

The area of development is divided into a specific property which is subject to a detailed development plan.

This newly formed property shall be assigned an identifier under the procedure of Article 26, Paragraph 3 of the Cadastre and Property Register Act.

What are the specifically regulated norms for building the landed property?

These norms are regulated in the text of Article 7, paragraph 2 of Ordinance No 19, namely: a/ density of construction - up to $20 \%$; b/ intensity of construction - up to 0.4 .

An important legal requirement from the text of Article 7, paragraph 3 of Ordinance No 19 is that the built-up area of the living quarters should not exceed $10 \%$ of the total built-up area of the farm buildings and buildings and not be more than 200 square meters.

The other legal characteristics of the buildings, which are constructed in agricultural lands without change of purpose, are reflected in the texts of art. 8, art. 9 and art.10 of Ordinance No. 19.

Who are they?

First, in the agricultural lands without changing the purpose, the buildings are designed with a height in accordance with the functional and technological requirements and a floor no more than two floors;

Second, the distance of the buildings from the boundaries between two neighboring properties in free build can not be less than three meters;

Third, the relative location of the buildings on the boundaries between two neighboring properties is allowed by mutual consent of the owners;

Fourth, in the agricultural lands without change of purpose, the designated areas for construction can be enclosed in compliance with the requirements of Art. 38, of the Spatial Development Act.

\section{Legal regime of permitting of construction on agricultural land without change of purpose.}

According to the wording of Article 11 (1) of Ordinance No 19, when an owner of an agricultural land (legal or natural person) wishes to carry out construction, the following package of documents shall be provided:

a/ request to the mayor of the municipality for construction on agricultural land without change of purpose. In this request, the purpose of the buildings to be built should be clarified; b/ property title document;

c/ sketch of the property issued by the municipal agricultural office or by the office of geodesy, geography and cadastre;

d/ Positive opinion from the Regional Directorate of Agriculture.

For the objects, which will be built in a property of up to 10 decares, the mayor of the municipality authorizes the elaboration of a detailed development plan.

Upon completion of these legal proceedings, a written building permit is issued on the basis of a written request from the owner of agricultural land.

According to the regulation of the text of Article 13 of Ordinance No 19, a building permit is issued by the Chief Architect of the Municipality on the basis of a written request by the owner of agricultural land.

The following documents shall be attached to the application for a building permit:

a/ document of ownership of the landed property;

b/ a detailed development plan or design visa; c/ investment project according to the provisions of Article 144, paragraph 1, item 3 of the Spatial Development Act; d/ permit for right of water use, power supply, etc.

The issued building permits or the refusals to issue a building permit shall be communicated to the interested persons under the procedure of Art. 149 of the Territorial Development Act. 


\section{CONCLUSION}

In its present form, the legal framework regulating the construction of agricultural lands without change of purpose in the Republic of Bulgaria is mainly complied with two basic legal aspects:

First, preservation of the purpose of agricultural land;

Second, observance of the norms and regulations for construction by the Spatial Development Act.

In order to be able to perform its legal role even more effectively, this regulatory framework needs to be refined which could focus on refining certain texts in the reviewed normative sources and incorporating new texts into them, namely:

Firstly, stepping up controls and introducing strict sanctions when the humus layer is not used;

Second, to introduce more detail in the regulation of the individual stages of construction;

Thirdly, regulating a compulsory study, as a phase of an expert group, of the characteristics of the agricultural property;

Fourthly, the maximum ignoring of the violations of the legal regulations, norms and prohibitions regarding the construction on agricultural land, which are located in the area of the Black Sea coast of the Republic of Bulgaria;

Fifth, regulation of more serious and coordinated control measures on construction in agricultural land without change of designation, with the participation of the bodies of the national construction control, the regional directorates of agriculture and the municipalities.

\section{REFERENCES}

1. Law on the Ownership and Use of Agricultural Land, o. State Gazette 17 of March 1, 1991, am. And dop. SG. No. 13 of February 7, 2017.

2. Law on the Conservation of Agricultural Land, o. SG 33 of 24 April 1996, amend. SG. No. 61 of 5 August 2016

3. Ordinance No. 19 of 25.10.2012. For construction in the agricultural lands without change of their purpose, in effect from 06.11.2012, issued by the Minister of Agriculture and Food and the Minister of Regional Development and Public Works, SG 85 of 6 November 2012

4. www.ciela.net 